\title{
Identification and validation of nebulized aerosol devices for sputum induction
}

\author{
Warren J Davidson $\mathrm{MD}^{1}$, John Dennis $\mathrm{PhD}^{1,2}$, Stephanie The $\mathrm{BSc}^{1}$, \\ Belinda Litoski RRT ${ }^{1}$, Cora Pieron $\mathrm{PhD}^{1,2}$, Richard Leigh MD PhD ${ }^{1}$
}

\begin{abstract}
WJ Davidson, J Dennis, S The, B Litoski, C Pieron, R Leigh. Identification and validation of nebulized aerosol devices for sputum induction. Can Respir J 2014;21(2):101-106.
\end{abstract}

BACKGROUND: Induced sputum cell counts are a noninvasive and reliable method for evaluating the presence, type and degree of airway inflammation in patients with asthma. Currently, standard nebulizer devices used for sputum induction in multiple patients are labelled as single-patient devices by the manufacturer, which conflicts with infection prevention and control requirements. As such, these devices cannot feasibly be used in a clinical sputum induction program. Therefore, there is a need to identify alternative nebulizer devices that are either disposable or labelled for multipatient use.

OBJECTIVE: To apply validated rigorous, scientific testing methods to identify and validate commercially available nebulizer devices appropriate for use in a clinical sputum induction program.

METHODS: Measurement of nebulized aerosol output and size for the selected nebulizer designs followed robust International Organization for Standardization methods. Sputum induction using two of these nebulizers was successfully performed on 10 healthy adult subjects. The cytotechnologist performing sputum cell counts was blinded to the type of nebulizer used.

RESULTS: The studied nebulizers had variable aerosol outputs. The AeroNeb Solo (Aerogen, Ireland), Omron NE-U17 (Omron, Japan) and EASYneb II (Flaem Nuova, Italy) systems were found to have similar measurements of aerosol size. There was no significant difference in induced sputum cell results between the AeroNeb Solo and EASYneb II devices.

DISCUSSION: There is a need for rigorous, scientific evaluation of nebulizer devices for clinical applications, including sputum induction, for measurement of cell counts.

CONCLUSION: The present study was the most comprehensive analysis of different nebulizer devices for sputum induction to measure cell counts, and provides a framework for appropriate evaluation of nebulizer devices for induced sputum testing.

Key Words: Aerosol testing; Nebulizer; Sputum

Induced sputum cell count measurements are a noninvasive, reliable method for evaluating the presence, type and degree of airway inflammation in patients with asthma and various other airway diseases (1-3). Sputum cell counts can be used clinically to assist with patient management, including characterization of asthma phenotypes that may benefit from emerging biological therapies (4-7), and titration of inhaled corticosteroid therapy in patients with asthma (8). Tailoring asthma management based on sputum eosinophil counts has been shown to be effective in reducing asthma exacerbations (9-12) and is now considered to be standard of care for the management of patients with moderate-severe asthma in the Canadian asthma guidelines (13).

A wide range of commercially available nebulizer devices are available for clinical and research use. Traditional jet nebulizers are available in several different formats: constant output, breath-enhanced and dosimetric output. Unlike jet nebulizers, ultrasonic devices do not use compressed airflow and have traditionally been used for sputum induction. Vibrating mesh nebulizers are designed to improve

\section{Le recensement et la validation de nébuliseurs pour l'induction des expectorations}

HISTORIQUE : La numération cellulaire dans les expectoration induites sont des méthodes non effractives et fiables pour évaluer la présence, le type et le degré d'inflammation des voies aériennes chez les patients asthmatiques. Les fabricants considèrent que les nébuliseurs standards actuellement utilisés pour l'induction des expectorations chez de multiples patients sont réservés à un seul patient, ce qui est contraire aux exigences de prévention et de contrôle des infections. L'utilisation de ces nébuliseurs n'est donc pas envisageable dans un programme clinique d'induction des expectorations. C'est pourquoi il est nécessaire de trouver des nébuliseurs qui sont jetables ou conçus pour être utilisés par de multiples patients.

OBJECTIF : Appliquer des méthodes rigoureuses d'essais scientifiques validés pour trouver et valider des nébuliseurs commercialisés qui peuvent être utilisés dans le cadre d'un programme clinique d'induction des expectorations.

MÉTHODOLOGIE : La mesure du débit d'aérosol nébulisé et la dimension des nébuliseurs sélectionnés respectaient la méthodologie solide de l'Organisation internationale de normalisation. On a réussi à induire les expectorations à l'aide de deux de ces nébuliseurs chez dix sujets adultes en santé. Le cytotechnologue qui effectuait la numération cellulaire dans les expectorations ne savait pas quel nébuliseur avait été utilisé.

RÉSULTATS : Les nébuliseurs à l'étude présentaient divers débits d'aérosol. Les chercheurs ont constaté que la dimension d'aérosol des systèmes AeroNeb Solo (Aerogen, Irlande), Omron NE-U17 (Omron, Japon) et EASYneb II (Flaem Nuova, Italie) était similaire. Les résultats de la numération cellulaire dans les expectorations des systèmes AeroNeb Solo et EASYneb II n'étaient pas significativement différents.

EXPOSÉ : Une évaluation scientifique rigoureuse des nébuliseurs s'impose pour mesurer la numération cellulaire dans des applications cliniques, y compris l'induction d'expectorations.

CONCLUSION : La présente étude était l'analyse la plus complète de différents nébuliseurs pour l'induction d'expectorations en vue de mesurer la numération cellulaire, et elle fournit un cadre d'évaluation convenable des nébuliseurs pour les tests d'expectoration induite.

the versatility, portability and efficiency of particle delivery (14). Established guidelines have stressed the need for performing rigorous, scientific testing of nebulizer devices for clinical applications (15). However, there remains a relative paucity of literature testing various nebulizer designs for use in sputum induction for the purposes of measuring sputum cell counts.

The desirable aerosol characteristics for sputum induction include a relatively low output and a large particle size (2). The range of nebulized aerosol sizes required for therapeutic respiratory deposition (including sputum induction) is $0.5 \mu \mathrm{m}$ to $5 \mu \mathrm{m}$ in a patient breathing at tidal volume (16). However, given that the aim of the present study was to determine nebulizer aerosol output characteristics (output and size) and identify a replacement nebulizer system with similar aerosol output properties, our study focused on comparing two nebulizers with a similar aerosol size and output with a well-established nebulizer device whose performance range is known to support sputum induction.

\footnotetext{
${ }^{1}$ Department of Medicine, University of Calgary; ${ }^{2}$ SolAero Ltd, Calgary, Alberta

Correspondence: Dr Warren J Davidson, Department of Medicine, University of Calgary, 7007-14th Street Southwest, Calgary, Alberta T2V 1P9.

Telephone 403-943-8864, fax 403-943-8666, e-mail wdavidso@ucalgary.ca
} 
In Calgary (Alberta), induced sputum collection and cell count analysis began in 2005 as part of the Department of Medicine Innovation Funding Program. The clinical use of induced sputum testing continues to increase and, to date, we have analyzed approximately 3100 clinical samples within the Calgary region and surrounding referral areas. Relatively low-output ultrasonic nebulizers, of which the Universal III ultrasonic nebulizer (Flaem Nuova, Italy) is a prototype, have been widely used throughout Canada, Europe and Australia for sputum induction. Recently, the manufacturer (Flaem Nuova, Italy) replaced this device with the EASYneb II ultrasonic nebulizer. However, both units are labelled as single-patient devices by the manufacturer and cannot be used on multiple patients as per infection prevention and control requirements. Therefore, there is a need for alternative nebulizer devices that are either disposable or labelled for multipatient use. The aim of the present study was to apply validated rigorous, scientific testing methods to identify and validate nebulizer devices appropriate for use in a clinical sputum induction program. Specifically, we aimed to identify nebulizer devices with aerosol characteristics comparable with the current 'gold standard' EASYneb II and would be appropriate for use in a large clinical sputum induction program.

\section{METHODS}

The present study was approved by the institutional research ethics board and written informed consent was obtained from all subjects.

\section{Study design}

The primary objectives were: to define the in vitro nebulized aerosol characteristics (aerosol output and aerosol size) of the Universal III and EASYneb II ultrasonic nebulizers; to screen a range of candidate alternative nebulizers for aerosol output and aerosol size using rigorous in vitro criteria; and to compare induced sputum cell counts in healthy adult subjects obtained using the EASYneb II ultrasonic nebulizer with a selected nebulizer device that was either disposable or labelled for multipatient use.

\section{Aerosol testing}

In vitro tests applied methods embodied in the European Standard EN13544-1 (17) and International Organization for Standardization (ISO) 27427 (16) protocols, which describe scientifically recognized methods for clinically relevant characterization of nebulized aerosols for assessing aerosol output and aerosol size. Tests were conducted at the SolAero Ltd cGMP laboratory at the University Research Centre in Calgary.

Criteria for nebulizer selection included disposable devices, single-patient devices or devices labelled for multipatient use. Additionally, nebulizers had to be commercially available, supported in Canada and approved, or pending approval, by the Canadian Standards Association (CSA) for use in a clinical setting. The final list of nebulizers included: Flaem Nuova Universal III ultrasonic nebulizer; Flaem Nuova EASYneb II ultrasonic nebulizer; Respigard II jet nebulizer (Vital Signs Colorado, USA); Misty Max 10 jet nebulizer (CareFusion, USA); AeroNeb Solo (Aerogen Ltd, Ireland); PARI LC Sprint (PARI Respiratory Equipment Inc, USA); and the Omron NE-U17 (Omron Healthcare Co, Ltd, Japan).

Testing of aerosol output incorporated sinusoidal breath simulation. Inhaled aerosol was collected on low-resistance filters (Filtrete, $3 \mathrm{M}, \mathrm{USA}$ ) and salt residue was subsequently assayed using ion-specific electrochemistry. Following initial testing of seven potentially suitable nebulizers for aerosol output, two specific nebulizers were then selected for aerosol size measurement, based on the following a priori established criteria: met current health authority requirements for infection control; in vitro characteristics of aerosol output; calculated time to complete patient sputum induction collection using the Universal III device as the baseline; ease of use by staff; and equipment costs, including purchase price, maintenance, cleaning and storage. Aerosol size measurement incorporated Next Generation Impactor (NGI) cascade impaction of saline aerosols and subsequent desorption of collected size fractions by ion-specific electrochemistry.

\section{Study subjects}

Healthy nonsmoking adult study participants were eligible provided they had normal spirometry (forced expiratory volume in $1 \mathrm{~s}\left[\mathrm{FEV}_{1}\right]$ $>80 \%$ predicted and $\mathrm{FEV}_{1}$ to forced vital capacity $[\mathrm{FVC}]$ ratio $\left[\mathrm{FEV}_{1} /\right.$ $\mathrm{FVC]}>0.75)$, with no significant bronchodilator response $\left(\mathrm{FEV}_{1}\right.$ and FVC $<200 \mathrm{~mL}$ increase and $<12 \%$ increase following short-acting bronchodilator administration). Potential study participants were excluded from the study if they had any of the following: a positive methacholine challenge test (defined here as a provocative concentration of methacholine required to yield a $20 \%$ reduction in baseline $\mathrm{FEV}_{1}\left[\mathrm{PC}_{20}\right]<16 \mathrm{mg} / \mathrm{mL}$ ); a smoking history $\geq 5$ pack years or had smoked within the past 12 months; a clinical history of atopy or allergic rhinitis; a diagnosed upper respiratory tract infection four weeks before study participation; or a history of any inflammatory condition considered by the investigators to be clinically relevant, including any underlying autoimmune disorder, infectious disease, immunodeficiency, malignancy or clinically relevant comorbidity. Women who were pregnant, or who were planning to become pregnant during the study period, and women who were breastfeeding were also excluded. Finally, only participants who provided written informed consent were included in the study.

Study subjects attended the laboratory on three separate occasions. During the initial screening visit, the subject's medical history was reviewed to determine whether they met inclusion/exclusion criteria. Suitable candidates were randomly assigned to undergo initial induced sputum collection with either the EASYneb II or the selected nebulizer device. At the second visit, subjects performed the first sputum induction. Forty-eight hours later (visit 3), they returned for the second sputum induction using the alternate nebulizer. The randomization sequence was computer-generated and stored in opaque, sealed envelopes held by an individual not involved in the study.

\section{Protocol}

Aerosol testing: For aerosol output testing, the test nebulizer containing $0.9 \%$ sodium chloride was fitted to a breath simulation device (Pari Compas Breathing Simulator, Pari GmbH, Germany), which simulated tidal breathing (sinus flow of $500 \mathrm{~mL}$ tidal volume at 15 breaths $/ \mathrm{min}$ ). Test nebulizers were operated according to the manufacturers' recommended flow rate. A low-resistance electrostatic filter fitted to the nebulizer mouthpiece collected all 'inhaled' nebulized aerosol. Aerosol residue was desorbed from collection filters and chloride was desorbed and quantified electrochemically, using a chloride ion-specific electrode (Jenway pH/ion model 3040 meter, Bibby Scientific Limited, United Kingdom) against known standards. The collected volume of deposited aerosol was then calculated and presented as $\mu \mathrm{L} / \mathrm{min}$ output rate, as well as total $\mu \mathrm{L}$ dose. Total nebulization time was also recorded.

For aerosol size testing, the test nebulizer containing $0.9 \%$ sodium chloride was adapted to fit a cascade impactor (M170 NGI, MSP Inc, USA). Test nebulizers were operated according to manufacturers' recommended flow rate (where appropriate). Emitted nebulized aerosol was drawn into the NGI at $15 \mathrm{~L} / \mathrm{min}$ and aerosol droplets were separated into different size fractions within the impactor over a timed $3 \mathrm{~min}$ collection period. Aerosol residues in each collection plate were quantitatively desorbed and the amount of chloride determined electrochemically. The amount of aerosol residue deposited on each stage was used to generate cumulative and normative size distributions, from which the mass median aerodynamic diameter (MMAD) and geometric SD of MMAD (GSD) were determined. The MMAD was defined as the diameter at which $50 \%$ of the particles by mass were larger and $50 \%$ were smaller. The GSD is a measure of the spread of an aerodynamic particle size distribution and typically calculated as follows: $\mathrm{GSD}=(\mathrm{d} 84 / \mathrm{d} 16) 1 / 2$, in which $\mathrm{d} 84$ and $\mathrm{d} 16$ represent the diameters at which $84 \%$ and $16 \%$ of the aerosol mass are contained Figure 1.

Sputum induction and processing: Sputum induction was performed using escalating doses of hypertonic saline as per standardized guidelines (18). Before nebulized saline administration, spirometry was 


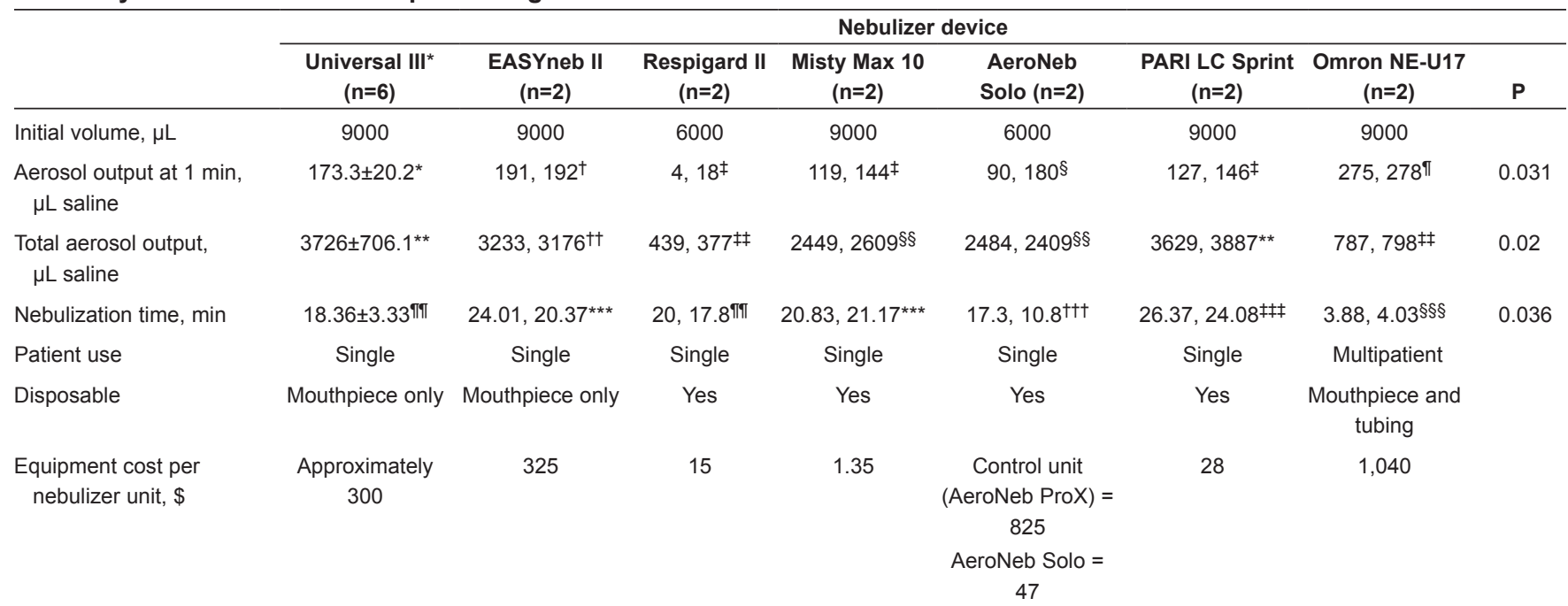

Published manufacturer's data were used to select suitable operating conditions and test volumes. $\mu \mathrm{L}$ saline $(0.9 \% \mathrm{~V} / \mathrm{V})$ was calculated as from the chloride ion standard curve $\left(y=8 E-05 x^{2}-0.1089 x+202.15\right)$. *Universal III, Flaem Nuova, Italy (data presented as mean $\left.\pm S D\right): P<0.05$ compared with Respigard II (Vital Signs Colorado Inc, USA), Misty Max 10 (CareFusion, USA), PARI LC Sprint (PARI Respiratory Equipment Inc, USA), Omron NE-U17 (Omron Healthcare Co, Ltd, Japan); †EASYneb II (Flaem Nuova, Italy): P<0.05 compared with Respigard II, Misty Max 10, AeroNeb Solo (Aerogen Ltd, Ireland), PARI LC Sprint; ${ }^{\ddagger}$ Respigard II, Misty Max 10 and PARI LC sprint: $P<0.05$ compared with Universal III, EASYneb II and Omron NE-U17; §AeroNeb Solo: P<0.05 compared with EASYneb II and Omron NE-U17. "Omron NE-U17: P<0.05 compared with Universal III, Respigard II, Misty Max 10, PARI LC Sprint, AeroNeb Solo; **Universal III, PARI LC Sprint: P<0.05 compared with Respigard II, Misty Max 10, AeroNeb Solo, Omron NE-U17; ${ }^{+\dagger} E A S Y$ neb II: P<0.05 compared with Respigard II and Omron NE-U17; $¥ \pm$ Respigard II and Omron NE-U17: P<0.05 compared with Universal III, EASYneb II and PARI LC Sprint; §§Misty Max 10 and AeroNeb Solo: P<0.05 compared with Universal III and PARI LC sprint; Tiा Universal III and Respigard II: P<0.05 compared with PARI LC Sprint and Omron NE-U17; ***EASYneb II and Misty Max 10: P<0.05 compared with AeroNeb Solo and Omron NE-U17; ${ }^{t+}$ AeroNeb Solo: P<0.05 compared with EasyNeb II, Misty Max 10 and Omron NE-U17; \#¥¥PARI LC Sprint: P<0.05 compared with Universal III, Respigard II, AeroNeb Solo and Omron NE-U17; \$\$\$Omron NE-U17: P<0.05 compared with Universal III, EasyNeb II, Respigard II, Misty Max 10 and PARI LC Sprint

performed, pre- and postbronchodilator, according to American Thoracic Society criteria (19). For the EASYneb II ultrasonic nebulizer, $9 \mathrm{~mL}$ of $4 \%$ sterile saline were placed into the well. The subject inhaled the nebulized mist for $7 \mathrm{~min}$ at tidal volume. At $7 \mathrm{~min}$, the subject was instructed to blow their nose, rinse their mouth with water, then cough and expectorate sputum into a specimen container. Spirometry was repeated to ensure the change in $\mathrm{FEV}_{1}$ was $<10 \%$ of baseline. These steps were repeated with $9 \mathrm{~mL}$ of $4 \%$ and $9 \mathrm{~mL}$ of $5 \%$ sterile saline. For the AeroNeb Solo device, the same procedure was used except $6 \mathrm{~mL}$ of the respective saline solutions were placed into the well, as per manufacturer's instructions.

After induction, samples were placed on ice and processed for differential cell counts using dithiothreitol within $2 \mathrm{~h}$ of collection (20). Total cell counts were obtained manually using a Bright-line Neubauer hemacytometer (Hausser Scientific, USA); the viability of each sample was assessed using the trypan blue exclusion method (21). Cells were diluted in phosphate-buffered saline to $1 \times 10^{6} / \mathrm{mL}$ and cytospin slides were prepared before being stained with Congo red for differential sputum cell counts. Samples were considered to be adequate for analysis if there was $<20 \%$ squamous cell contamination and a 400 nonsquamous cell differential cell count could be obtained. Measurements were compared with reported normal values (22). Cell counts were performed by an experienced cytotechnologist blinded to subject characteristics and nebulizer device used.

\section{Analysis}

Aerosol results were compared using the Kruskal-Wallis test. Where a significant effect was detected, appropriate post hoc testing was used to assess where that difference existed. Values from the different sputum collections were compared using the paired $t$ test for normally distributed data and the Wilcoxon signed-rank test for nonparametric data; $\mathrm{P}<0.05$ was considered to be statistically significant.

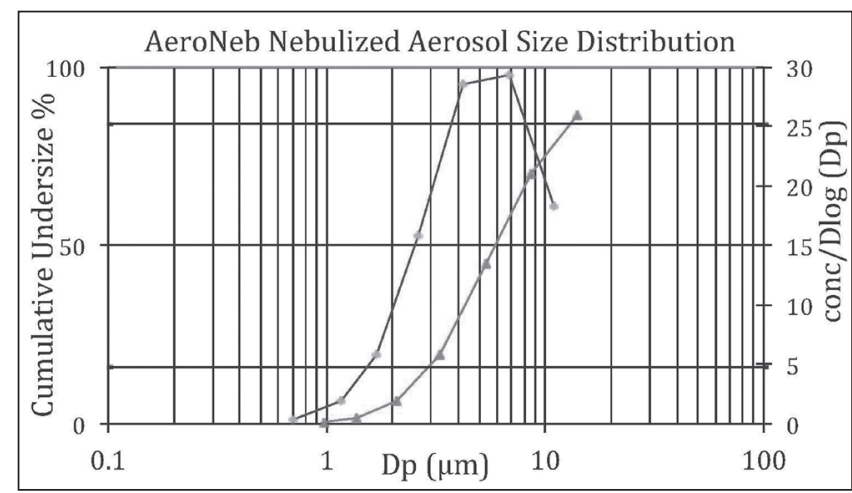

Figure 1) The plots show two expressions of a typical nebulized aerosol size distribution. The $x$-axis defines nebulized aerosol droplet (Dp) size between $0.1 \mu \mathrm{m}$ and $100 \mu \mathrm{m}$ in a log-normal scale. The cumulative size distribution (triangles) plots the cumulative mass of size fractions obtained from a nextgenration cascade impactor $(15 \mathrm{~L} / \mathrm{min}$ flow) and relates to the left $y$-axis (cumulative undersize \%). From the cumulative size plot, the mass median aerodynamic diameter can be determined as the size intercepting the 50\% cumulative mass, which is $5.9 \mu \mathrm{m}$ in this example. The circles represent a normative plot of the same size distribution whose shape indicates a near symmetrical log-normal distribution typical of many nebulized aerosol size distributions. AeroNeb (Aerogen Ltd, Ireland); conc Concentration

Aerosol output testing

\section{RESULTS}

Table 1 summarizes the results of the aerosol output testing. Given that the Universal III device has historically been viewed the gold standard (13) nebulizer for sputum induction in Canada, six of these 
TABLE 2

Summary results of aerosol size testing

\begin{tabular}{lcccc}
\hline & $\begin{array}{c}\text { Universal III** } \\
(\mathbf{n}=6)\end{array}$ & $\begin{array}{c}\text { AeroNeb Solo } \\
(\mathbf{n}=\mathbf{2})\end{array}$ & $\begin{array}{c}\text { Omron NE-U17 } \\
(\mathbf{n}=\mathbf{2})\end{array}$ & \multicolumn{1}{c}{$\mathbf{P}^{\S}$} \\
\hline MMAD, $\mu \mathrm{m}$ & $4.9 \pm 0.1 \pi$ & $5.1 \pm 5.9$ & $5.2 \pm 5.6$ & 0.035 \\
GSD & $2.17 \pm 0.08$ & $2.1 \pm 2.2$ & $2 \pm 2.1$ & 0.19 \\
FPF \% $<5 \mu \mathrm{m}$ & $51.5 \pm 2.1 \pi$ & $47 \pm 41$ & $46 \pm 44$ & 0.035 \\
\hline
\end{tabular}

Data presented as mean $\pm S D$ unless otherwise indicated. ${ }^{*}$ Flaem Nuova, Italy; ${ }^{\dagger}$ Aerogen Ltd, Ireland; ${ }^{\ddagger}$ Omron Healthcare Co, Ltd, Japan; §KruskalWallis test; TUniversal III: $P<0.05$ compared with AeroNeb Solo, Omron NE-U17. FPF Fine particle fraction with aerosol mass; GSD Geometric SD of the mass median aerodynamic diameter (MMAD)

\section{TABLE 3}

\section{Baseline characteristics of subjects}

\begin{tabular}{|c|c|}
\hline Characteristic & \\
\hline Age, years & $35.4 \pm 13.1$ \\
\hline Male:female, n:n & $1: 9$ \\
\hline \multicolumn{2}{|l|}{ Ethnicity, n (\%) } \\
\hline Caucasian & $8(80)$ \\
\hline Asian & $2(20)$ \\
\hline Body mass index, $\mathrm{kg} / \mathrm{m}^{2}$ & $22.8 \pm 4.3$ \\
\hline Smoking, pack-years & $0 \pm 0$ \\
\hline $\mathrm{FEV}_{1}, \mathrm{~L}$ & $3.68 \pm 0.63$ \\
\hline $\mathrm{FEV}_{1}, \%$ predicted & $117 \pm 13$ \\
\hline FVC, L & $4.42 \pm 0.85$ \\
\hline FVC, \% predicted & $120 \pm 18$ \\
\hline $\mathrm{FEV}_{1} / \mathrm{FVC}$ & $0.82 \pm 0.07$ \\
\hline
\end{tabular}

Data presented as mean $\pm S D$ unless otherwise indicated. FEV ${ }_{1}$ Forced expiratory volume in $1 \mathrm{~s}$; FVC Forced vital capacity

devices were tested to establish baseline data with which the other nebulizer devices were then compared. The results in Table 1 show that the aerosol output at $1 \mathrm{~min}$ for the Universal III device was different than the Respigard II and Omron NE-U17 devices; it was similar for all the other devices. Total nebulization time was similar among all devices except the Omron NE-U17.

\section{Aerosol size testing}

After the initial aerosol output testing was completed, two nebulizer devices were then chosen for measurement of aerosol size and comparison with the Universal III. Criteria for selection of the nebulizers included: met current health authority requirements for infection control; in vitro characteristics of aerosol output; calculated time to complete patient sputum induction collection using the Universal III device as the baseline; ease of use by staff; and equipment costs, including purchase price, maintenance, cleaning and storage. The AeroNeb Solo was chosen because it is a readily available, small, relatively inexpensive, single-use disposable unit that had aerosol output similar to the Universal III. Furthermore, the calculated time for induced sputum collection was not greater than current practice and the pulmonary laboratory staff performing sputum induction found it easy to use. The Omron NE-U17 was also chosen because it is labelled for multipatient use, and is easy to use and could reduce the time needed for the induced sputum procedure. The ability to calibrate aerosol output with the Omron NE-U17 was believed to be beneficial when testing a broad clinical spectrum of patients (ie, the nebulizer output can be adjusted depending on how the patient tolerates the sputum induction procedure).

The results of aerosol size testing are summarized in Table 2. All three devices had similar MMAD and GSD. The Universal III had a marginally larger fine particle fraction of aerosol mass $<5 \mu \mathrm{m}$ (fine particle fraction $\%<5 \mu \mathrm{m})$.
TABLE 4

Sputum cell count results

\begin{tabular}{lccl}
\hline & EASYneb $\mathbf{~ I}^{*}$ & Aeroneb Solo $^{\dagger}$ & \multicolumn{1}{c}{$\mathbf{P}^{\ddagger}$} \\
\hline Total cell count, $\times 10^{6} / \mathrm{g}$ & $4.90(3.33-9.27)$ & $4.25(1.95-6.93)$ & 0.92 \\
Viability, \% & $83.5(50-90.6)$ & $86(77.4-92.9)$ & 0.084 \\
Neutrophils, \% & $35.35(19.8-58)$ & $42.1(18-53)$ & 0.49 \\
Neutrophils, $\times 10^{6} / \mathrm{g}$ & $2.06(0.41-3)$ & $1.43(0.32-3.42)$ & 0.49 \\
Eosinophils, \% & $0.6(0.3-2.3)$ & $0.6(0-0.8)$ & 0.57 \\
Eosinophils, $\times 10^{6} / \mathrm{g}$ & $0.025(0.0017-0.077)$ & $0.047(0-0.057)$ & 0.73 \\
Macrophages, $\%$ & $64.4(39.7-80.3)$ & $58.7(47.1-81.8)$ & 0.49 \\
Macrophages, $\times 10^{6} / \mathrm{g}$ & $2.62(1.32-4.79)$ & $2.14(0.95-3)$ & 0.63 \\
\hline
\end{tabular}

Data presented as median (interquartile range). *Flaem Nuova, Italy; ${ }^{\dagger}$ Aerogen Ltd, Ireland; $¥$ Wilcoxon signed-rank test

\section{Induced sputum cell counts}

At the time the present study was conducted, the Omron NE-U17 had not yet received CSA approval for clinical use in Canada. As a result, we chose to proceed with the AeroNeb Solo device. Given that the original Universal III model had been replaced by the manufacturer (FlaemN, Italy) with the the EASYneb II, the induced sputum cell counts obtained using the AeroNeb Solo device were compared with those obtained using the EASYneb II. Fourteen healthy adult subjects were tested, with 10 providing adequate sputum samples; two inadequate sputum samples were obtained from each type of nebulizer. Subject characteristics at baseline are listed in Table 3. The majority of the subjects were Caucasian $(n=8)$ and female $(n=9)$. The study population had normal spirometry and airway responsiveness $\left(\mathrm{PC}_{20}\right.$ $>16 \mathrm{mg} / \mathrm{mL}$ ). None of the subjects were taking regular medications at the time of enrollment. The sputum cell count results are summarized in Table 4. There were no significant differences in cell viability, and total and differential sputum cell counts between the two devices. No subjects experienced symptomatic bronchospasm or a $>10 \%$ decrease in $\mathrm{FEV}_{1}$ following administration of hypertonic saline.

\section{DISCUSSION}

Currently, standard nebulizer devices used for sputum induction are labelled as single-patient devices by the manufacturer and cannot be used on multiple patients as per infection prevention and control requirements. As such, these devices cannot feasibly be used in a large clinical sputum induction program. Therefore, there is a need for alternative nebulizer devices that are either disposable or labelled for multipatient use. To date, the present study was the most comprehensive analysis objectively assessing different nebulizer devices for use in performing sputum induction for the purposes of measuring sputum cell counts. When compared with the gold standard Universal III ultrasonic nebulizer, the different devices had variable aerosol outputs. Aerosol size testing showed that both the AeroNeb Solo and Omron NE-U17 systems had slightly larger aerosol size than the EASYneb II, but were considered to be equivalent in terms of the aerosol deposition associated with tidal-flow breathing patterns and with nebulized aerosol administration. There were no differences in the induced sputum cell counts obtained using either the EasyNeb II or the AeroNeb devices. Our study provides a framework for the appropriate evaluation of nebulizer devices for induced sputum testing. This framework adheres to the strict European Respiratory Society guidelines for nebulizer testing and selection for clinical applications (15).

In an earlier study assessing the use of induced sputum cell counts, Pin et al (23) used the Fisoneb ultrasonic nebulizer (Canadian Medical Products Ltd, Canada), which was then used in other sputum induction studies $(2,24)$. The Fisoneb nebulizer became the precursor of the Medix ultrasonic nebulizer (Clement Clarke International Ltd, United Kingdom), which was then used in various applications of sputum induction $(25,26)$. Both the Fisoneb and Medix ultrasonic nebulizers have highly similar aerosol characteristics. Belda et al (27) compared the relatively low output, large particle size Medix ultrasonic nebulizer with the higher output smaller particle size DeVilbiss 
Ultraneb 99 nebulizer (DeVilbiss Co, USA). There were no significant differences observed with regard to sputum cell counts between the two nebulizers, although the higher output nebulizer did result in lower eosinophilic cationic protein and interleukin-8 levels within the sputum fluid-phase. More recently, Loh et al (28) compared a Taiwanese-made compressed air nebulizer (BestNeb, Apex Medical Corp, Taiwan) with an ultrasonic nebulizer, Medix Sonix 2000 (Clement Clarke International Ltd, United Kingdom). Sixteen healthy adult subjects underwent sputum induction with the different devices with either hypertonic saline or isotonic saline. The ultrasonic nebulizer and hypertonic saline resulted in higher total sputum cell counts and improved cell viability. There was no difference in the differential cell counts. There were several limitations of this particular study including the assessment of only two nebulizer devices and the lack of aerosol testing. The order of nebulizer use was not randomized. Furthermore, the sputum induction procedures were performed over four weeks, increasing the chance of external factors affecting the sputum cell count. The current study extends our knowledge in the area of sputum induction by performing rigorous aerosol testing on several commercially available nebulizer devices and controlling for the potential limitations identified in earlier studies.

When comparing aerosol output among different designs, the most useful metric is the aerosol output rate (ie, the volume of aerosol 'inhaled' by a patient in $1 \mathrm{~min}[\mu \mathrm{L} / \mathrm{min}]$ ) (29). This metric enables comparison of various nebulizer designs that may require different volume fills of test saline. With a focus on aerosol output rate, a suitable alternative nebulizer was deemed to be one that would provide a similar rate to the Universal III. The EASYneb II provided a similar output rate but was not a suitable alternative due to the fact that it is labelled as a single-patient device. The Respigard II had a very low aerosol output rate of $11 \mu \mathrm{L} / \mathrm{min}$. The MistyMax 10 and the PARI LC Sprint, both jet nebulizers, along with the AeroNeb Solo, a vibrating mesh nebulizer, had an aerosol output rate on the lower end of the Universal III. When tested at maximum settings (airflow and nebulization rate), the Omron NE-U17 had an aerosol output rate higher than the Universal III. The overall aerosol output for the Omron unit appeared to be lower than other nebulizers due to a large dead volume (the minimum volume of saline required by the unit to produce an aerosol). The MMAD, as a single unit description of aerosol size, is the most useful metric for evaluating different systems (30). The AeroNeb Solo and the Omron NE-U17 were found to have similar MMADs compared with the EasyNeb II device.

Determining whether induced sputum cell counts differ among different nebulizer devices is an important clinical question. Sputum cell counts can be used clinically to assist with management of airway inflammation, including titration of inhaled corticosteroid therapy in asthma management (9). Given that we wanted to assess changes in sputum cell counts only related to the type of nebulizer device, and not related to underlying airway disease, we chose to study healthy, nonsmoking subjects. In an effort to reduce systematic bias, we randomized the type of nebulizer device used for the first induced sputum collection. Although the respiratory therapist performing the induced sputum test could not be blinded to the nebulizer device, the cytotechnologist preparing the samples and performing the cell counts was blinded to the type of nebulizer. We scheduled the second induced sputum collection $48 \mathrm{~h}$ after the first collection because repeated induced sputum procedures within $48 \mathrm{~h}$ have been shown to alter the cellular composition of sputum (31-33).

There were a few limitations to the present study. First, the choice of nebulizer devices was limited to those that were CSA approved and commercially available and supported in Canada. Second, we did not assess whether sputum fluid-phase mediators, such as sputum cytokines, differed among the nebulizer devices. Third, testing was not performed on patients with asthma. However, given that the principle aim of the present study was to assess changes in sputum cell counts related only to the type of nebulizer device, we did not include subjects with asthma. Having identified the AeroNeb Solo as being the best candidate among seven potential nebulizers in the present study among healthy subjects, future studies will now focus on comparing the AeroNeb Solo with the EASYneb II nebulizer in patients with asthma and other inflammatory airway diseases. Fourth, we did not perform a formal cost analysis. However, compared with the cost of the single-patient device EASYneb II (\$325), the AeroNeb Solo was substantially less expensive (\$47) in Canada.

\section{CONCLUSION}

The present analysis was the most comprehensive study formally assessing different nebulizer devices for use in performing sputum induction for the purposes of measuring sputum cell counts. The various nebulizers we tested had variable aerosol outputs. The AeroNeb Solo, Omron NE-U17 and EASYneb II systems were found to have similar measurements of aerosol size. We found no significant difference in the induced sputum cell counts obtained with the AeroNeb Solo and the EASYneb II devices. Consequently, we have formally adopted the AeroNeb Solo device as the nebulizer of choice in our clinical sputum induction program at the University of Calgary. Our study provides a framework for the rigorous, scientific evaluation of nebulizer devices for induced sputum testing using accepted guidelines.

ACKNOWLEDGEMENTS: The authors are grateful to Omron for supplying nebulizers for testing.

ETHICS APPROVAL: Institutional Research Ethics Board, University of Calgary, Calgary, Alberta.

DISCLOSURES: Warren Davidson, Stephanie The, Belinda Litoski, and Richard Leigh have no potential conflicts of interest related to this study. John Dennis and Cora Pieron own and operate SolAero Ltd (Calgary, Alberta).

\section{REFERENCES}

1. Djukanović R, Sterk PJ, Fahy JV, Hargreave FE. Standardised methodology of sputum induction and processing. Eur Respir J 2002;20(37 Suppl):1s-55s.

2. Pizzichini E, Pizzichini M, Efthimiadis A, et al. Indices of airway inflammation in induced sputum. Reproducibility and validity of cell and fluid-phase measurements. Am J Respir Crit Care Med 1996;154:308-17.

3. Pizzichini E, Pizzichini MM, Leigh R, Djukanović R, Sterk PJ Safety of sputum induction. Eur Respir J 2002;(Suppl 37):9S-18.

4. Haldar P, Brightling CE, Hargadon B, et al. Mepolizumab and exacerbations of refractory eosinophilic asthma. N Engl J Med 2009;360:973-84.

5. Pavord ID, Korn S, Howarth P, et al. Mepolizumab for severe eosinophilic asthma (DREAM): A multicentre, double-blind, placebo-controlled trial. Lancet 2012;380:651-9.

6. Corren J, Lemanske RF, Hanania NA, et al. Lebrikizumab treatment in adults with asthma. N Engl J Med 2011;365:1088-98.

7. Piper E, Brightling C, Niven R, et al. A phase II placebo-controlled study of tralokinumab in moderate-to-severe asthma. Eur Respir J 2013;41:330-8

8. Petsky HL, Kynaston JA, Turner C, et al. Tailored interventions based on sputum eosinophils versus clinical symptoms for asthma in children and adults. Cochrane Database Syst Rev 2007;(2):CD005603.

9. Green RH, Brightling CE, McKenna S, et al. Asthma exacerbations and sputum eosinophil counts: A randomized controlled trial. Lancet 2002;360:1715-21.

10. Jayaram L, Pizzichini MM, Cook RJ, et al. Determining asthma treatment by monitoring sputum cell counts: Effect on exacerbations. Eur Resp J 2006;27:483-94.

11. Chlumský J, Striz I, Terl M, Vondracek J. Strategy aimed at reduction of sputum eosinophils decreases exacerbation rate in patients with asthma. J Int Med Res 2006;34:129-39.

12. Greene CD, Kelly MM, Hawkins DH, Evans JA, Davidson WJ, Leigh R. The introduction of induced sputum cell counts in hospital-based asthma clinics significantly reduces asthma-related emergency room visits. Chest 2007;132;437S. 
13. Lougheed MD, Lemiere C, Ducharme FM, et al; Canadian Thoracic Society Asthma Clinical Assembly. Canadian Thoracic Society 2012 guideline update: Diagnosis and management of asthma in preschoolers, children, and adults. Can Respir J 2012;19:127-64.

14. Dennis JH. New developments in nebulizer technology. In: Boe J, O'Driscoll R, Dennis JH, eds. Practical Handbook of Nebulizer Therapy. London: Martin Dunitz, 2003.

15. Boe J, Dennis JH, O'Driscoll BR, et al; European Respiratory Society Task Force on the use of nebulizers. European Respiratory Society Guidelines on the use of nebulizers. Eur Respir J 2001;18:228-42.

16. International Organization for Standardization (ISO) 27427:2010. Anaesthetic and respiratory equipment - Nebulizing systems and components. 2010.

17. European Standard NF (EN) 13544-1:2009. Respiratory therapy equipment. Nebulizing systems and their components. 2009.

18. Efthimiadis A, Spanevello A, Hamid Q, et al. Methods of sputum processing for cell counts, immunocytochemistry and in situ hybridisation. Eur Respir J 2002;(Suppl 37):19s-23s.

19. Miller MR, Hankinson J, Brusasco V, et al. Standardisation of spirometry. Eur Respir J 2005;26:319-38.

20. Pizzichini E, Pizzichini MM, Efthimiadis A, Hargreave FE, Dolovich J. Measurement of inflammatory indices in induced sputum: Effects of selection of sputum to minimize salivary contamination. Eur Respir J 1996;9:1174-80.

21. Strober W. Trypan blue exclusion test of cell viability. Curr Protoc Immunol 2001;Appendix 3:Appendix 3B.

22. Belda J, Leigh R, Parameswaran K, O'Byrne PM, Sears MR, Hargreave FE. Induced sputum cell counts in healthy adults. Am J Respir Crit Care Med 2000;161:475-8.

23. Pin I, Gibson PG, Kolendowicz R, et al. Use of induced sputum cell counts to investigate airway inflammation in asthma. Thorax 1992;47:25-9.

24. Pizzichini MM, Pizzichini E, Clelland L, et al. Sputum in severe exacerbations of asthma: Kinetics of inflammatory indices after prednisone treatment. Am J Resp Crit Care Med 1997;155:1501-8.
25. Hargreave FE, Leigh R. Induced sputum, eosinophilic bronchitis, and chronic obstructive pulmonary disease. Am J Respir Crit Care Med 1999;160(5 Pt 2):S53-7.

26. Leigh R, Belda J, Kelly MM, Cox G, Squillace DL, Gleich GJ, Hargreave FE. Eosinophil cationic protein relates to sputum neutrophil counts in healthy subjects. J Allergy Clin Immunol 2000;106:593-4.

27. Belda J, Hussack P, Dolovich M, Efthimiadis A, Hargreave FE. Sputum induction: Effect of nebulizer output and inhalation time on cell counts and fluid-phase measures. Clin Exp Allergy 2001;31:1740-4.

28. Loh LC, Eg KP, Puspanathan P, et al. A comparison of sputum induction methods: ultrasonic vs compressed-air nebulizer and hypertonic vs isotonic saline inhalation. Asian Pac J Allergy Immunol 2004;22:11-7.

29. Dennis JH. Drug nebuliser design and performance: Breath enhanced jet vs. constant output jet vs. ultrasonic. J Aerosol Med 1995;8:277-80.

30. Dennis JH. Theory and science of nebulizer use and clinical implications. In: Boe J, O’Driscoll R, Dennis JH, eds. Practical Handbook of Nebulizer Therapy. Martin Dunitz, 2003:3-18.

31. Holz O, Richter K, Jörres RA, Speckin P, Mücke M, Magnussen H. Changes in sputum composition between two inductions performed on consecutive days. Thorax 1998;53:83-6.

32. Nightingale JA, Rogers DF, Barnes PJ. Effect of repeated sputum induction on cell counts in normal volunteers. Thorax 1998;53:87-90.

33. van der Vaart H, Postma DS, Timens W, Kauffman HF, Hylkema MN, Ten Hacken NH. Repeated sputum inductions induce a transient neutrophilic and eosinophilic response. Chest 2006;130:1157-64. 


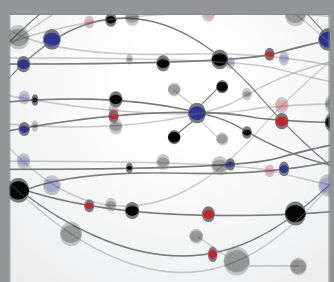

The Scientific World Journal
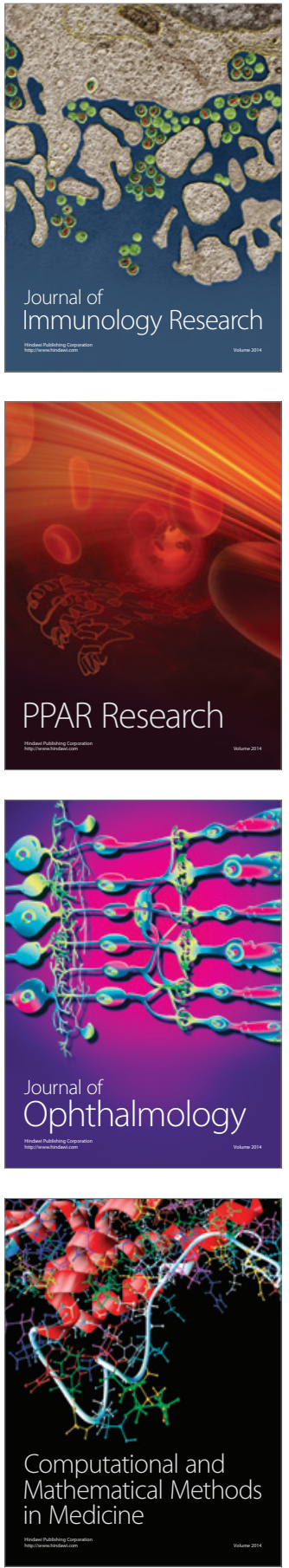

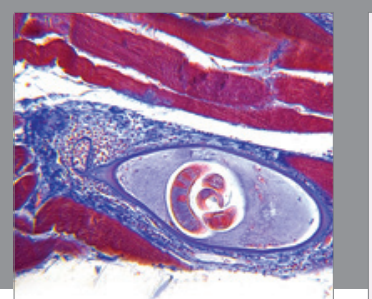

Gastroenterology Research and Practice

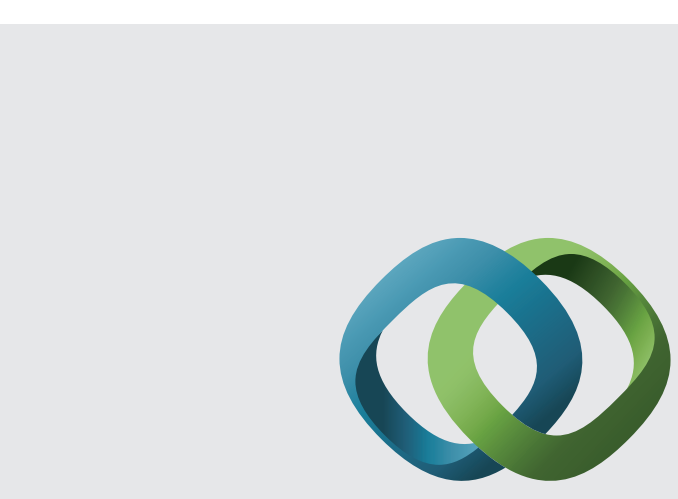

\section{Hindawi}

Submit your manuscripts at

http://www.hindawi.com
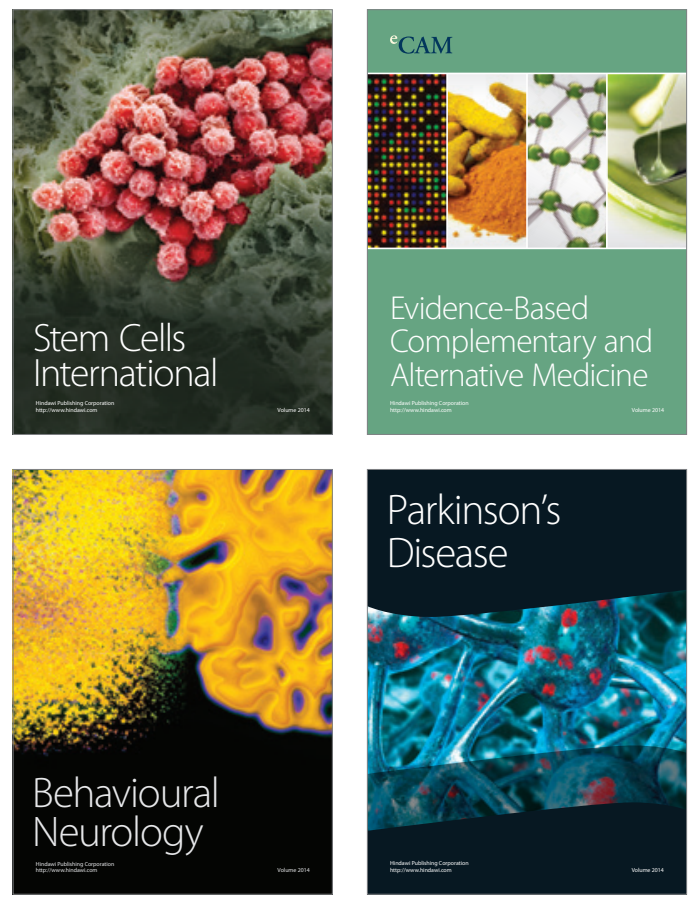
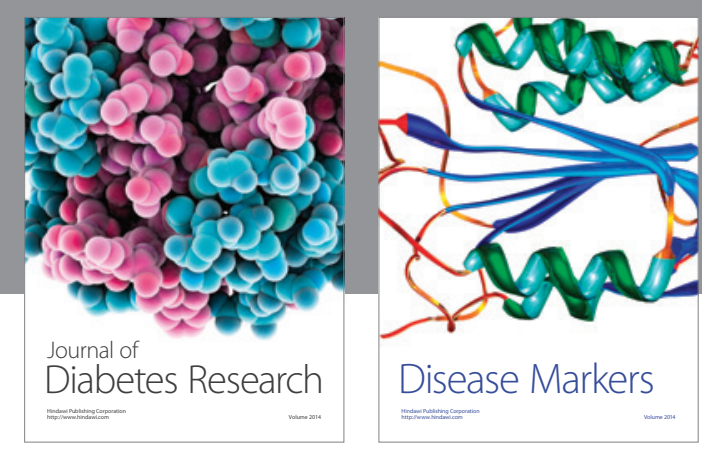

Disease Markers
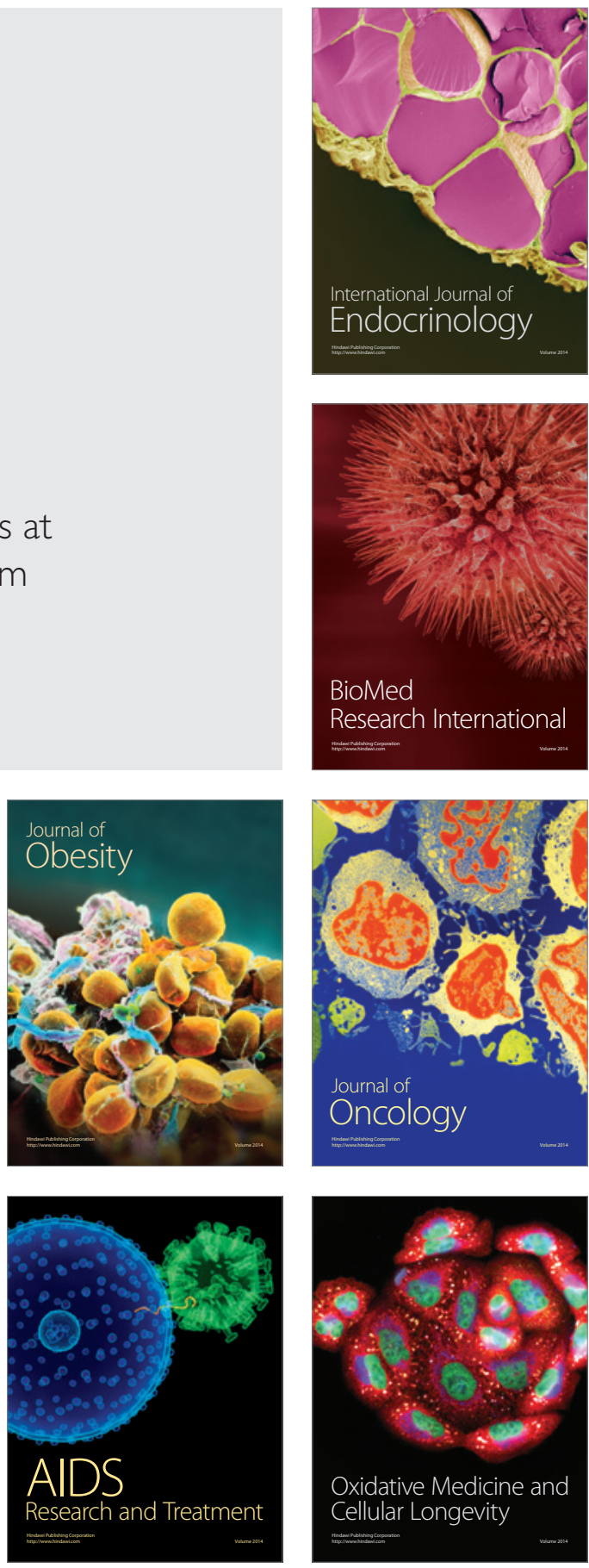